\title{
Association between dietary patterns and sociodemographics: a cross-sectional study of Australian nursing students
}

\author{
Susan Williams ${ }^{1}$, Corneel Vandelanotte ${ }^{1}$, Christopher Irwin ${ }^{2}$, Nick Bellissimo ${ }^{3}$, Penny \\ Heidke $^{4}$, Sonia Saluja ${ }^{5}$, Amornrat Saito ${ }^{6}$, Saman Khalesi ${ }^{1 *}$ \\ ${ }^{1}$ Physical Activity Research Group, Appleton Institute, School of Health Medical and \\ Applied Sciences, Central Queensland University, Rockhampton, Australia \\ ${ }^{2}$ School of Allied Health Sciences, Griffith University, Gold Coast, Australia \\ ${ }^{3}$ School of Nutrition, Ryerson University, Toronto, Canada \\ ${ }^{4}$ School of Nursing, Midwifery and Social Sciences, Central Queensland University, \\ Rockhampton, Australia \\ ${ }^{5}$ School of Health Medical and Applied Sciences, Central Queensland University, \\ Rockhampton, Australia
}

${ }^{6}$ Menzies Health Institute Queensland and School of Nursing and Midwifery, Griffith University, Logan campus, Australia

Correspondence: Saman Khalesi (MSc, R.Nut., PhD), Physical Activity Research Group, Appleton Institute, School of Health, Medical and Applied Sciences, Central Queensland University, Rockhampton, 4701 QLD, Australia. Phone:

+610749306970, email: s.khalesi@cqu.edu.au; saman.khalesi@gmail.com

Running title: Dietary pattern of nursing students

Declarations: This work was supported by the CQUniversity's New Staff Research Grant (grant number: RSH4337). 


\begin{abstract}
Lack of time, financial issues and stressful clinical and educational environments in nursing studies promote higher intakes of convenience and fast foods loaded in fat and sugar, which are linked to reduced mental and physical health. This study examined the dietary patterns of nursing students and their associated sociodemographic factors to inform the development of future health promotion interventions. A total of 548 Bachelor of Nursing students were invited to complete a survey. Associations were explored using chi-square and logistic regression. Three dietary patterns were identified: Healthy (loaded in fruit, vegetables and legumes), Western (loaded in fat, sugar and salty snacks); and Unbalanced. Only $21 \%$ of participants were classified with a Healthy dietary pattern, which were more likely to be older ( $>35$ years old) and have a personal annual income between $\$ 20,000-\$ 59,999$ and $\$ 60,000$ - $\$ 99,999$. Students with $1-2$ and $\geq 3$ children were more likely to follow Western dietary pattern. There is a need to develop interventions to improve the dietary behaviors of nursing students by health-promoting activities and provision of online health resources.
\end{abstract}

Keywords: Diet; Nursing students; Western diet; Demography 


\section{Introduction}

For many students, the transition from high school to university life may negatively affect their physical and mental wellbeing (Deliens, Clarys, De Bourdeaudhuij, \& Deforche, 2014). Demands associated with making everyday life and financial decisions, forming new peer and social relationships and handling high study workloads can increase psychological distress (Lee, Ahmed, Pathirana, \& Papier, 2016). This may lead to the adoption of risky lifestyle behaviors such as binge drinking, drug use, overeating and a decline in physical activity (Lloyd-Richardson, Bailey, Fava, \& Wing, 2009; Vadeboncoeur, Townsend, \& Foster, 2015). Unhealthy behaviour and poor eating patterns are linked to lower academic achievement (Burrows, Whatnall, Patterson, \& Hutchesson, 2017), poorer psychological health (e.g. depression and anxiety) (Wattick, Hagedorn, \& Olfert, 2018) and obesity (de Vos et al., 2015). It is important to explore nursing students' patterns of eating and sociodemographic factors associated with unhealthy patterns to inform the development of health promotion programs and interventions to improve general health and academic performance in nursing students.

\subsection{Literature review}

University students adopt unhealthy eating behaviour in response to a range of individual, social and environmental factors (Deliens et al., 2014; Martinez, Harmon, Nigg, Bantum, \& Strayhorn, 2016; Sogari, Velez-Argumedo, Gómez, \& Mora, 2018) and may gain or lose weight (Brown, 2008; Gropper, Simmons, Connell, \& Ulrich, 2012) in response to psychological stress (Boyce \& Kuijer, 2015), changes in diet and/or increased alcohol consumption (de Vos et al., 2015). Recent dietary intake data indicate that Australian university students are not meeting dietary recommendations for core food groups (C. Irwin, Desbrow, Khalesi, \& McCartney, 2019; Mantzioris, Wilson, Tan, \& Villani, 2017; Papier, Ahmed, Lee, \& Wiseman, 2015). This is of particular importance because unhealthy dietary 
behaviour (e.g. low intakes of fruit and vegetables, and breakfast/meal skipping) in university students, are associated with higher levels of stress (Lee et al., 2016) and lower academic achievement (Burrows et al., 2017), motivation to improve lifestyles (de Vos et al., 2015) and the ability to empathize with others (Brehm et al., 2016). Although university students typically demonstrate an awareness of the negative impact of unhealthy food intake, convenience and taste are often higher priorities that drive their consumption behaviour (Abraham, Noriega, \& Shin, 2018). Academic stress combined with time and budget restrictions contribute to students' adoption of unhealthy eating patterns; thus, the sacrifice of healthy food choices for convenience and 'comfort foods' high in sugar, fat and salt (Unusan, 2006; Vadeboncoeur et al., 2015).

Students undertaking health-related degrees/programs (e.g. nursing, medicine, physiotherapy) may experience additional stress because of their requirements for completion of clinical placement activities (i.e. in a hospital or healthcare environment). In these situations, students often encounter a range of new and challenging learning experiences associated with patient care, including critical illness, physical disorders and disabilities, psychological disorders and death (Muncer, Taylor, Green, \& McManus, 2001). Nurses and nursing students work closely with patients in providing direct care and serving as patient advocates (Hyland, 2002) and expectations exist for nurses and nursing students to be role models to patients and families and exemplars of good health practices (Darch, Baillie, \& Gillison, 2017) - thus setting them apart from other health professions and university students. Nursing and other health-related students may acquire skills and knowledge in health and promotion practices during their education/training, increasing their awareness of health behaviour risks (Peltzer, Pengpid, Yung, Aounallah-Skhiri, \& Rehman, 2016). However, this knowledge is often not applied to their personal behaviour and they have similar health behaviour risk as other students (Horneffer, 2006; Peltzer et al., 2016; Stark, Manning-Walsh, \& Vliem, 2005). 
Nurses experience higher rates of physical and mental health disorders and conditions compared to other employed persons (Virtanen et al., 2012). A recent study of approximately 650 Australian nurses found approximately two-thirds had chronic physical health conditions and 27\% reported mental health and wellbeing conditions (Smyth, Lindsay, Holmes, Gardner, \& Rahman, 2016). A recent study of over 5000 Nurses and Midwives in New South Wales, Australia, found that compared to older nurses, younger nurses (under 34 years) less commonly met recommended fruit and vegetable intakes and consumed fast food and soft drinks more frequently (Perry et al., 2018). A recent study of mainly young nursing students (Mean age 24.5 years) in Scotland found that compared to the general population, lower proportions of students were meeting recommendations for fruit and vegetable intakes, but a lower proportion of students were consuming takeaway meals (Evans et al., 2019).

Across health-related undergraduate programs, nursing students have typically reported higher levels of academic and external stress than students enrolled in other programs (i.e. physiotherapy, pharmacy, dentistry, medicine) (Stecker, 2004). A review of nursing students reported workloads and assignment as main stressors (L. J. Labrague et al., 2017). Nursing students also have high stress when caring for patients in their academic placements (Coetzee \& Klopper, 2010; L. J. Labrague et al., 2017), or when still adapting/adjusting to changes in academic and clinical requirements (L.J. Labrague, 2013). Nursing students may also undertake shift work and additional part-time or full-time work (Salamonson \& Andrew, 2006) that disturbs time management and lifestyle behaviour (Wong, Wong, Wong, \& Lee, 2010) and limits academic performance (Pitt, Powis, Levett-Jones, \& Hunter, 2012), compounding the stress associated with study loads and assignment completion (L.J. Labrague, 2013). Thus, the complexity of nursing studies imposes a high level of stress on students that may directly impact dietary behaviors and increase the risk of health-related risk factors such as the development of overweight/obesity (Yau \& Potenza, 2013). 
For nursing students newly exposed to clinical environments and caring for others, personal health, diet and lifestyle may have lower priority than their study and clinical workload. The stressful nature of nursing studies along with lack of time and budget (or their management skills) may lead students to opt for ready-to-eat, processed, fast foods and vending machine snacks high in saturated fats, trans fats, salt and sugar, which are often readily available in clinical hospital environments (Winston, Sallis, Swartz, Hoelscher, \& Peskin, 2013). Similar to practicing nurses, nursing students may also find it difficult to make changes to their lifestyle behaviour when involved in clinical placements that include shift work, stress and emotional labor (Perry et al., 2018).

\subsection{Study Aim}

Literature examining the dietary habits of university and nursing students, especially in an Australian context, is scarce. The current body of evidence suggests that many university students adopt unhealthy lifestyle behaviour as a result of a range of individual, social and environmental factors and nursing students may be at risk of poorer health behaviour and dietary patterns due to the additional pressures of clinical placement and clinical experiences associated with caring for others. Existing evidence supports the provision of healthy eating interventions for university students (Martinez et al., 2016; Sogari et al., 2018) and including self-care education in nurses curriculum (Horneffer, 2006; Stark et al., 2005). Therefore, the development of healthier dietary behaviour in nurses, may help to address issues with student dropout and retention in the nursing workforce and support nurses to establish and maintain healthier lifestyles and work as positive role models to their patients. A first step to understanding what is needed in providing nursing students with nutrition education, is to understand nurse's dietary patterns. Hence, this study aimed to examine the dietary patterns of nursing students and sociodemographic factors associated with these patterns to inform the 
development of future health promotion activities for students enrolled in a Bachelor of Nursing program.

\section{Methods}

\subsection{Design and Participants}

This cross-sectional study included students enrolled in a Bachelor of Nursing (BN) program at two Australian universities (Central Queensland University (CQU), Rockhampton and Griffith University, Gold Coast). Convenience and snowball sampling methods were used to recruit nursing students from each university via student emails, university online learning management systems, nursing program Facebook pages and study flyers. Nursing students were also approached by researchers and invited to participate. They were also asked to invite their peers and classmates to complete the survey. Eligible participants were individuals aged $\geq 18$ years enrolled in the BN at CQU or Griffith University (either part-time or full-time) in any academic year (first, second, third). Those who were pregnant, breastfeeding (due to different dietary requirements), or unable to provide written informed consent (at the beginning of the questionnaire) were excluded.

\subsection{Data collection}

Survey data was collected between May and September 2017 at CQU and between February and June 2018 at Griffith University using the SurveyMonkey (SurveyMonkey Inc. San Mateo, California, USA, www.surveymonkey.com) interface. Food and dietary habits were measured using a Food Frequency Questionnaire (FFQ) (59 items) previously validated in an Australian population (J. C. Irwin, Khalesi, Fenning, \& Vella, 2017; Khalesi, Sharma, Irwin, $\&$ Sun, 2016). Participants were asked to report their food consumption frequency in the past 12 months in daily, weekly or monthly format using a 10-point scale (from 'Never' to ' $3-5$ 
times per day'). Intake of supplements, fast food and restaurant foods, the frequency of meals, and special dietary regimens were also recorded. Sociodemographic information including age, gender, education, personal annual income, living arrangements and clinical placement status were also collected. This was a self-reported survey completed by participants. Ethics approvals were obtained from the CQU Human Research Ethics Committee (Project Number: H17/02-016) and Griffith University Human Ethics Committee (Protocol number: GU 2017/649) prior to study commencement.

\subsection{Data management and analysis}

Participants with $\geq 50 \%$ of data missing from the survey and any missing data from FFQ were excluded from subsequent analysis. All weekly and monthly food frequencies were converted to a daily equivalent. Food items were classified into the five main food groups (i.e. fruit, vegetables and legumes, dairy and alternatives, meat and alternatives, grains and cereals) or 'discretionary foods' groups based on the Australian Dietary Guidelines (ADG) (National Health and Medical Research Council, 2013) and the serving size of each food group was calculated based on the frequency of intake and portion sizes outlined in the ADG. Daily energy and nutrient intakes were analyzed using FoodWorks version 7 dietary analysis software (Xyris Software, High Gate Hill, Qld, Australia). Dietary information for participants with extremes in total daily energy intake $<2,500 \mathrm{~kJ}$ or $>18,000 \mathrm{~kJ}$ were excluded from the analysis (Khalesi, Doshi, Buys, \& Sun, 2016).

Cronbach's alpha was used to check the internal consistency reliability of the FFQ. An alpha value $>0.70$ was considered acceptable reliability (Okada, 2015). Explanatory factor analysis with principal component analysis followed by Varimax rotation was used to drive dietary factors. The Kaiser-Meyer-Olkin test with level $>0.50$ was used to confirm sample adequacy of factor analysis. All factors with eigen values $>1.00$ were extracted. Food items belonged to 
the extracted factor if they had a factor loading $\geq 0.40$ or $\leq-0.40$. Extracted factors were named based on the loaded food items. A factor score was calculated from the sum of the food items loaded for each food factor. K-mean cluster analysis was conducted to identify the most meaningful cluster formation from extracted factors with at least $10 \%$ of the sample size in each cluster. Analysis of variance (ANOVA) with Tukey post hoc was conducted to compare the distribution of food factors among clusters. Each cluster was named as a dietary pattern based on their loaded food factors and known characteristics of dietary patterns. Logtransformation was used to improve the normality of factors before analysis if they were not normally distributed.

To confirm the characteristics of dietary patterns, participants' intake of the five main food groups and discretionary foods were compared to recommendations included in the ADG (National Health and Medical Research Council, 2013). This was investigated further by comparing energy and nutrient intake between dietary patterns. Analysis of variance (ANOVA) with Tukey post hoc (for parametric variables) or independent-samples tests with Kruskal-Wallis test (for nonparametric variables) was used to compare food groups, energy and nutrients intake among dietary patterns. Statistical significance was accepted at $\mathrm{p}<0.05$. Variables were presented in frequency (\%), mean and standard deviation (SD), or median (percentile).

The distribution of sociodemographic variables among dietary patterns was compared using cross tabulation and Chi-square analysis. The association between sociodemographic variables with a significant bivariate distribution among dietary patterns and the desirable dietary pattern (the healthiest dietary pattern) was further investigated using logistic regression. Likelihood of having the desirable dietary pattern was shown by odds ratio with 95\% confidence interval (CI). Statistical significance was accepted at $\mathrm{p}<0.05$. 


\section{Results}

A total of $670 \mathrm{BN}$ students attempted the survey. Of these 27 did not meet the screening criteria (10 were pregnant and 17 were younger than 18 years of age) and were not able to complete the survey. 102 students had more than $50 \%$ of data missing and were excluded from the analysis. $548 \mathrm{BN}$ students completed the survey, including 321 students from CQU and 227 students from Griffith University. Of these, 48 participants had $\geq 50 \%$ of FFQ data missing and were excluded from the final analysis. Thirteen participant's data were also excluded due to extreme total daily energy intake $<2,500 \mathrm{~kJ}(\mathrm{n}=8)$, or $>18,000 \mathrm{~kJ}(\mathrm{n}=5)$. A total of 487 participants were included in the final dietary analysis. Characteristics of included participants are presented in Table 1. Of those included in the final analysis, $58 \%$ were from CQU and $42 \%$ from Griffith University. The majority of nursing students in this study were female (94.5\%), Caucasian (83\%), enrolled in their program/degree between 2015-2018 (87.5\%), were studying full-time (71\%), with no prior nursing experience (66\%). Around half of the students lived with their partners (49.5\%), were married or were in a De facto relationship (57\%), with no children (57\%). Most students were earning less than $\$ 60,000$ a year (78\%) and working $11-60$ hours per week $(66 \%)$.

The FFQ (59 dietary items) showed an acceptable internal consistency with Cronbach's alpha of 0.76 . Factor analysis with Varimax rotation results are presented in Table 2. The KaiserMeyer-Olkin $(\mathrm{KMO})$ value of 0.75 suggested adequate sample size $(\mathrm{p}<0.001)$. Eigenvalues $>1.00$ and Scree plots suggested extraction of 19 factors explaining $62.8 \%$ of the total variance. Extracted factors were named based on loaded items and presented in Table 2. Nuts, Fresh fruit, and Bread (white) food items were loaded $<0.40$ (or $>-0.40$ ) in all factors and were excluded from factor analysis and scoring.

Cluster analysis of food factors revealed three distinct clusters. Cluster A accounted for $21 \%$ $(n=104)$, cluster B for $31 \%(n=150)$ and cluster $C$ for $48 \%(n=233)$. Table 3 shows the 
distribution of food factors between clusters. Cluster A had the highest factor score for Vegetables \& Legumes, Fruit, Single nutrient \& Probiotic supplements, Vitamins, Fish oil supplements \& Green tea, Water and Tea compared to the rest. Cluster B had the highest score of Snack \& Fast foods, Salt, Oil \& Sugar, Meat, Sugary foods, Low-fat Dairy and Bread (wholegrain) compared to the rest. Factor $\mathrm{C}$ had no distinct characteristics in the distribution of food factors and was generally lower in all food factor scores compared to the other clusters. These clusters were further named according to their overall dietary characteristics as: Healthy (Cluster A), Western (Cluster B) and Unbalanced (Cluster C). The number of serves for each of the food groups (mean (SD)) consumed by participants is presented in Table 4. Compared to the recommended daily number of serves (based on recommendations from the ADG (National Health and Medical Research Council, 2013) for women aged 19-50 years as these represented the majority of participants), participants consumed fewer serves of all core food groups but two to five times more serves of discretionary foods. Intakes of the core food groups were also compared between the three dietary patterns (Table 4). A higher intake of dairy and alternatives, and discretionary foods was observed in those following the Western dietary pattern. Those following the Healthy dietary pattern had a higher intake of vegetables and legumes/beans. Those with an Unbalanced dietary pattern also had a higher intake of discretionary foods compared with the ADG, and lower intake of all core food groups. No other distinct characteristics were observed. These differences confirm the characteristics of the extracted dietary patterns.

Differences in macro- and micro-nutrient composition between the three dietary patterns are reported in Table 5 as mean $\pm \mathrm{SD}$ or median, $25^{\text {th }}$ to $75^{\text {th }}$ percentile. Analysis of daily energy and nutrient intakes found that participants classified in the Healthy dietary pattern had a median energy intake and the highest intake of most vitamins and minerals. Participants following the Western dietary pattern had the highest intake of energy, saturated fatty acids, 
trans fatty acids, sugar and percentage energy from fat compared to other dietary patterns. No distinction in macro- and micro-nutrients intake was observed in participants following the Unbalanced dietary pattern.

Significant differences in distribution across dietary patterns were found for age $\left(\chi^{2}: 14.3\right.$, $\mathrm{p}=0.006)$, personal income $\left(\boldsymbol{\chi}^{2}: 17.39, \mathrm{p}=0.03\right)$, living arrangements $\left(\boldsymbol{\chi}^{2}: 18.33, \mathrm{p}=0.02\right)$, number of children $\left(\chi^{2}: 14.78, p=0.005\right)$, and prior nursing experience $\left(\chi^{2}: 15.78, p=0.01\right)$ (See Table 6). Results of logistic regression analysis and the associations between dietary patterns and sociodemographic and university/training variables are also reported in Table 6. Students following the Healthy dietary pattern were most likely to be over the age of 35 years (OR: 1.79, $\mathrm{p}=0.04)$ or earn between $\$ 60000$ and $\$ 99999$ per year (OR: 2.32, $\mathrm{p}=0.02)$.

Students following the Western dietary pattern were more likely to be $>35$ years of age (OR: 1.62, $\mathrm{p}=0.044)$, have $1-2$ children (OR: $1.96, \mathrm{p}=0.003)$ or $\geq 3$ children $(\mathrm{OR}: 1.80, \mathrm{p}=0.031)$. Students following the Unbalanced dietary pattern were less likely to be between 25-35 (OR: $0.54, \mathrm{p}=0.007)$ or $>35$ years of age $(\mathrm{OR}: 0.45, \mathrm{p}<0.001)$, have $1-2(\mathrm{OR}: 0.48, \mathrm{p}=0.001)$ or $>$ 3 (OR: $0.60 \mathrm{p}=0.049$ ) children, or earn between $\$ 20000$ and $\$ 59999$ per year (OR: 0.52, $\mathrm{p}=0.002)$

\section{Discussion}

This study of Australian undergraduate nursing students explored patterns of dietary intake and associated sociodemographic and university training factors. Overall, the results indicate that nursing students are not meeting recommendations for intakes of core food groups and exceeding recommendations for discretionary foods. We identified three distinctly different dietary patterns (Healthy, Western and Unbalanced) with the overall majority of students following either the Western (31\%) or Unbalanced dietary patterns (48\%). The Western dietary pattern (high in discretionary foods, dairy and alternatives but low in fruit, vegetables 
and grains) contributes to higher intakes of energy $(8000 \mathrm{~kJ})$, total fat $(82 \mathrm{~g})$ (including saturated (32g), trans (1.4g), polyunsaturated (9.5g) and monounsaturated (33g) fats), cholesterol (358mg) and sugar (83g), compared to the other patterns. The unbalanced dietary pattern describes a diet that does not meet the recommended servings of any of the core food groups and is generally low in energy $(5500 \mathrm{~kJ})$. These results highlight that a majority of nursing students in this study were either consuming unhealthy diets or had disordered eating patterns that may be associated with higher levels of stress (Lee et al., 2016), negative physical and psychological health outcomes (Wattick et al., 2018), lower academic achievement (Burrows et al., 2017) and weight gain (de Vos et al., 2015). These findings highlight a need to develop interventions that promote healthy eating behaviour in nursing students. Such interventions could be developed in consultation with university students (Martinez et al., 2016; Sogari et al., 2018) and include strategies such as labelling healthy food options (Sogari et al., 2018), hands-on nutrition skills, online support services (Martinez et al., 2016) and provide education on associations between dietary intakes/behaviors, stress (Lee et al., 2016) and academic achievement (Burrows et al., 2017).

Our findings for associations between a Healthy dietary pattern and age and income, align with previous research indicating that younger university students adopt unhealthy behaviour when facing a combination of academic time and budget stressors (Unusan, 2006; Vadeboncoeur et al., 2015), and/or when struggling to adapt to the transitory demands associated with university study (L.J. Labrague, 2013; Lloyd-Richardson et al., 2009). With most of the participants studying full-time but also working at least 21 hours per week, they may be experiencing greater stress as a result of managing fulltime study and their additional hours in paid work (Lee et al., 2016; Salamonson \& Andrew, 2006). It would be prudent to ensure students are appreciative of these stressors when commencing their studies. 
Interventions to promote healthy eating behaviors in students should also include strategies to promote time management and budgeting skills.

The Western dietary patterns were highest in snack and fast foods and more likely followed by older students with children. These findings align with an earlier study (Bryer, Cherkis, \& Raman, 2013) that found older students with multiple life roles have less ability or desire to participate in health-promoting behaviors. These findings also suggest that students with families may have developed a greater reliance on convenience foods to assist in managing family and university study loads and this may also contribute further to psychological stress (Lee et al., 2016). With approximately $30 \%$ of the student cohort having one or more children, our findings reinforce the need to provide health promotion to nurses as part of their curriculum in addition to providing programs that aim to enhance skills in time and stress management (Bryer et al., 2013). In addition, university staff should provide advice to nursing students about the need to prepare healthy and quick meals that can meet nutritional needs (Deliens et al., 2014). This is especially important during periods of high study loads and when students are working in hospital/healthcare settings where snack foods and convenience foods are often readily available (Deliens et al., 2014; Winston et al., 2013).

We did not find significant associations between dietary patterns and the nursing specific university training related factors (including previous nursing experience, enrolment status, clinical placement status) in this study. Literature suggests that factors such as academic stress, time and budget restrictions similarly influence nursing and non-nursing university students (Unusan, 2006; Vadeboncoeur et al., 2015). It may however, also be explained by the limited number of nursing specific university training-related factors included in this study. Future research of university students' dietary patterns should include a wider range of individual, social and environmental factors (e.g. measures of stress, weight and health status, shift work, living location, university and workplace environments) (Lo, 2002; Yau \& 
Potenza, 2013) and include a mix of students from both nursing and other university programs.

This study shows that nursing students generally have poor dietary intakes and dietary patterns similar to other university students (Lee et al., 2016; Mantzioris et al., 2017; Papier et al., 2015). Although this study identified three different dietary patterns, none of our dietary patterns represents meeting recommendations for servings of core food groups or discretionary foods (National Health and Medical Research Council, 2013). This highlights the extent of unhealthy eating in students that is similarly reflected in recent national dietary intake data (Australian Bureau of Statistics, 2016).

To our knowledge, this is the only study analyzing the dietary patterns of nursing students enrolled in the BN program and their sociodemographic differences. A strength of this study is that it included nursing students from two different universities (one regional and one metropolitan university) in Australia. However, this study has several limitations. The dietary information collected in this study was from a self-reported FFQ. Although dietary patterns identified using factor and cluster analysis are recognized for their value in the epidemiological studies, FFQs are often criticized for their subjective nature and may not be representative of participant's actual food intake. Nevertheless, the FFQ used in this study was previously validated in a sample of Australian adults (J. C. Irwin et al., 2017). Recruitment of participants and subsequent survey completion occurred throughout a teaching term and the rates of participation were greater in the starting weeks of the teaching term compared to the final weeks when students often have assignments due and exams to complete (and may be more time poor and stressed). Although this may have resulted in students reporting healthier food intakes in the earlier part of the term when they were less stressed or time poor, our comparison between students that were on clinical placement at the time of the survey compared to those not on placement did not show any significant 
difference. Finally, the lack of diversity in the distribution of some demographic variables (e.g. gender and ethnicity) in the population limited the analysis of the association between sociodemographic variables and dietary patterns.

With only a few studies of university students conducted in Australia, more extensive research is needed to understand the relationships between dietary intakes and longer-term outcomes for students. For nursing students who are acknowledged as being at greater risk of academic and external stress it will be important for university staff to develop strategies that will assist these students in developing and maintaining healthier dietary behaviors. Further research that explores changes in dietary intakes over the academic year and duration of the nursing program would contribute understanding of any temporal changes and possible adaptations made by students as they progress through their study program.

\section{Conclusion}

This study found that most nursing students adhere to unhealthy or unbalanced eating patterns. Further research is necessary to understand factors contributing to these dietary patterns and their impact on the student's physical and psychological wellbeing. Findings from this study provide a first step to developing targeted interventions for undergraduate nursing students to improve their dietary intakes and behaviors and their overall health and wellbeing.

\section{Acknowledgement:}

This work was supported by the CQUniversity's New Staff Research Grant (grant number: RSH4337). 


\section{Author contributions:}

Study design: SW, SK, CV, SS, NB

Data collection: SK, PH, CI \& AS

Data analysis: SK \& PH

Manuscript writing: SW, SK, CV \& CI

\section{References}

Abraham, S., Noriega, B. R., \& Shin, J. Y. (2018). College students eating habits and knowledge of nutritional requirements. Journal of Nutrition and Human Health, 2(1), 13-17.

Australian Bureau of Statistics, A. (2016). Australian Health Survey: Consumption of Food Groups from the Australian Dietary Guidelines, 2011-12. Retrieved from Canberra: http://www.abs.gov.au/ausstats/abs@.nsf/Lookup/4364.0.55.012main+features12011-12

Boyce, J. A., \& Kuijer, R. G. (2015). Perceived stress and freshman weight change: the moderating role of baseline body mass index. Physiol Behav, 139, 491-496. doi:10.1016/j.physbeh.2014.12.011

Brehm, B. J., Summer, S. S., Khoury, J. C., Filak, A. T., Lieberman, M. A., \& Heubi, J. E. (2016). Health Status and Lifestyle Habits of US Medical Students: A Longitudinal Study. Ann Med Health Sci Res, 6(6), 341-347. doi:10.4103/amhsr.amhsr_469_15

Brown, C. (2008). The information trail of the 'Freshman 15'--a systematic review of a health myth within the research and popular literature. Health Info Libr J, 25(1), 1-12. doi:10.1111/j.1471-1842.2007.00762.x

Bryer, J., Cherkis, F., \& Raman, J. (2013). Health-Promotion Behaviors of Undergraduate Nursing Students: A Survey Analysis. Nursing Education Perspectives, 34(6), 410-415. doi:10.5480/11614

Burrows, T. L., Whatnall, M. C., Patterson, A. J., \& Hutchesson, M. J. (2017). Associations between Dietary Intake and Academic Achievement in College Students: A Systematic Review. Healthcare (Basel), 5(4). doi:10.3390/healthcare5040060

Coetzee, S. K., \& Klopper, H. C. (2010). Compassion fatigue within nursing practice: a concept analysis. Nurs Health Sci, 12(2), 235-243. doi:10.1111/j.1442-2018.2010.00526.x

Darch, J., Baillie, L., \& Gillison, F. (2017). Nurses as role models in health promotion: a concept analysis. Br J Nurs, 26(17), 982-988. doi:10.12968/bjon.2017.26.17.982

de Vos, P., Hanck, C., Neisingh, M., Prak, D., Groen, H., \& Faas, M. M. (2015). Weight gain in freshman college students and perceived health. Prev Med Rep, 2, 229-234. doi:10.1016/j.pmedr.2015.03.008

Deliens, T., Clarys, P., De Bourdeaudhuij, I., \& Deforche, B. (2014). Determinants of eating behaviour in university students: a qualitative study using focus group discussions. BMC Public Health, 14(1), 53. doi:10.1186/1471-2458-14-53

Gropper, S. S., Simmons, K. P., Connell, L. J., \& Ulrich, P. V. (2012). Changes in body weight, composition, and shape: a 4-year study of college students. Appl Physiol Nutr Metab, 37(6), 1118-1123. doi:10.1139/h2012-139

Horneffer, K. J. (2006). Students' self-concepts: implications for promoting self-care within the nursing curriculum. J Nurs Educ, 45(8), 311-316.

Hyland, D. (2002). An Exploration of the Relationship Between Patient Autonomy and Patient Advocacy: implications for nursing practice. Nursing Ethics, 9(5), 472-482.

doi:10.1191/0969733002ne537oa 
Irwin, C., Desbrow, B., Khalesi, S., \& McCartney, D. (2019). Challenges following a personalised diet adhering to dietary guidelines in a sample of Australian university students. Nutr Health, 260106019841247. doi:10.1177/0260106019841247

Irwin, J. C., Khalesi, S., Fenning, A. S., \& Vella, R. K. (2017). The effect of lipophilicity and dose on the frequency of statin-associated muscle symptoms: A systematic review and meta-analysis. Pharmacol Res. doi:10.1016/j.phrs.2017.09.013

Khalesi, S., Doshi, D., Buys, N., \& Sun, J. (2016). Validation of a short food frequency questionnaire in Australian adults. International Journal of Food Sciences and Nutrition, 1-9. doi:10.1080/09637486.2016.1240763

Khalesi, S., Sharma, S., Irwin, C., \& Sun, J. (2016). Dietary patterns, nutrition knowledge and lifestyle: associations with blood pressure in a sample of Australian adults (the Food BP study). $J$ Hum Hypertens, 30(10), 581-590. doi:10.1038/jhh.2016.22

Labrague, L. J. (2013). Stress, Stressors, and Stress Responses of Student Nurses in a Government Nursing School. Health Science Journal, 7(4), 424-435. Retrieved from http://www.hsj.gr/medicine/stress-stressors-and-stress-responses-of-student-nurses-in-agovernment-nursing-school.pdf

Labrague, L. J., McEnroe-Petitte, D. M., Gloe, D., Thomas, L., Papathanasiou, I. V., \& Tsaras, K. (2017). A literature review on stress and coping strategies in nursing students. J Ment Health, 26(5), 471-480. doi:10.1080/09638237.2016.1244721

Lee, P. C., Ahmed, F., Pathirana, T. I., \& Papier, K. (2016). Factors associated with stress among firstyear undergraduate students attending an Australian university. Food and Nutrition Report, 1(3), 17-24. Retrieved from https://epublications.bond.edu.au/hsm pubs/1524/

Lloyd-Richardson, E. E., Bailey, S., Fava, J. L., \& Wing, R. (2009). A Prospective Study of Weight Gain During the College Freshman and Sophomore Years. Preventive medicine, 48(3), 256-261. doi:10.1016/j.ypmed.2008.12.009

Lo, R. (2002). A longitudinal study of perceived level of stress, coping and self-esteem of undergraduate nursing students: an Australian case study. J Adv Nurs, 39(2), 119-126.

Mantzioris, E., Wilson, N., Tan, S. Y., \& Villani, A. (2017). Australian first-year university students are not meeting Australian guide to healthy eating guidelines. Journal of Nutrition and Intermediary Metabolism, 8(June), 114. Retrieved from https://ac.elscdn.com/S2352385917302153/1-s2.0-S2352385917302153-main.pdf? tid=db6d3ea0-b3c54092-8d40-51049380de98\&acdnat=1540860200 b0720737894adaa4d3978da6efb5f768

Martinez, Y. T. S., Harmon, B. E., Nigg, C. R., Bantum, E. O., \& Strayhorn, S. (2016). Diet and Physical Activity Intervention Strategies for College Students. Health behavior and policy review, 3(4), 336-347. doi:10.14485/HBPR.3.4.5

Muncer, S., Taylor, S., Green, D. W., \& McManus, I. C. (2001). Nurses' representations of the perceived causes of work-related stress: A network drawing approach. Work \& Stress, 15(1), 40-52. doi:10.1080/02678370120688

National Health and Medical Research Council, N. (2013). Australian Dietary Guidelines. Retrieved from Canberra:

Okada, K. (2015). Bayesian meta-analysis of Cronbach's coefficient alpha to evaluate informative hypotheses. Res Synth Methods, 6(4), 333-346. doi:10.1002/jrsm.1155

Papier, K., Ahmed, F., Lee, P., \& Wiseman, J. (2015). Stress and dietary behaviour among first-year university students in Australia: sex differences. Nutrition, 31(2), 324-330. doi:10.1016/j.nut.2014.08.004

Peltzer, K., Pengpid, S., Yung, T. K., Aounallah-Skhiri, H., \& Rehman, R. (2016). Comparison of health risk behavior, awareness, and health benefit beliefs of health science and non-health science students: An international study. Nurs Health Sci, 18(2), 180-187. doi:10.1111/nhs.12242

Perry, L., Xu, X., Gallagher, R., Nicholls, R., Sibbritt, D., \& Duffield, C. (2018). Lifestyle Health Behaviors of Nurses and Midwives: The 'Fit for the Future' Study. Int J Environ Res Public Health, 15(5). doi:10.3390/ijerph15050945 
Pitt, V., Powis, D., Levett-Jones, T., \& Hunter, S. (2012). Factors influencing nursing students' academic and clinical performance and attrition: An integrative literature review. Nurse Educ Today, 32(8), 903-913. doi:https://doi.org/10.1016/i.nedt.2012.04.011

Salamonson, Y., \& Andrew, S. (2006). Academic performance in nursing students: influence of parttime employment, age and ethnicity. J Adv Nurs, 55(3), 342-349; discussion 350-341. doi:10.1111/j.1365-2648.2006.03863_1.x

Smyth, W., Lindsay, D., Holmes, C., Gardner, A., \& Rahman, K. M. (2016). Self-reported long-term conditions of nurses and midwives across a northern Australian health service: A survey. Int J Nurs Stud, 62, 22-35. doi:10.1016/j.ijnurstu.2016.07.008

Sogari, G., Velez-Argumedo, C., Gómez, M. I., \& Mora, C. (2018). College Students and Eating Habits: A Study Using An Ecological Model for Healthy Behavior. Nutrients, 10(12), 1823. doi:10.3390/nu10121823

Stark, M. A., Manning-Walsh, J., \& Vliem, S. (2005). Caring for self while learning to care for others: a challenge for nursing students. J Nurs Educ, 44(6), 266-270.

Stecker, T. (2004). Well-being in an academic environment. Medical Education, 38, 465-478. Retrieved from https://onlinelibrary.wiley.com/doi/epdf/10.1046/j.1365-2929.2004.01812.x

Unusan, N. (2006). Linkage between stress and fruit and vegetable intake among university students: an empirical analysis on Turkish students. Nutrition Research, 26(8), 385-390. doi:https://doi.org/10.1016/i.nutres.2006.06.002

Vadeboncoeur, C., Townsend, N., \& Foster, C. (2015). A meta-analysis of weight gain in first year university students: is freshman 15 a myth? BMC Obes, 2, 22. doi:10.1186/s40608-015-00517

Virtanen, M., Vahtera, J., Batty, G. D., Tuisku, K., Oksanen, T., Elovainio, M., ... Kivimaki, M. (2012). Health risk behaviors and morbidity among hospital staff--comparison across hospital ward medical specialties in a study of 21 Finnish hospitals. Scand J Work Environ Health, 38(3), 228-237. doi:10.5271/sjweh.3264

Wattick, R. A., Hagedorn, R. L., \& Olfert, M. D. (2018). Relationship between Diet and Mental Health in a Young Adult Appalachian College Population. Nutrients, 10(8). doi:10.3390/nu10080957

Winston, C. P., Sallis, J. F., Swartz, M. D., Hoelscher, D. M., \& Peskin, M. F. (2013). Consumer Nutrition Environments of Hospitals: An Exploratory Analysis Using the Hospital Nutrition Environment Scan for Cafeterias, Vending Machines, and Gift Shops, 2012. Preventing Chronic Disease, 10, E110. doi:10.5888/pcd10.120335

Wong, H., Wong, M. C., Wong, S. Y., \& Lee, A. (2010). The association between shift duty and abnormal eating behavior among nurses working in a major hospital: a cross-sectional study. Int J Nurs Stud, 47(8), 1021-1027. doi:10.1016/j.ijnurstu.2010.01.001

Yau, Y. H. C., \& Potenza, M. N. (2013). Stress and eating behaviors. Minerva endocrinologica, 38(3), 255-267. Retrieved from https://www.ncbi.nlm.nih.gov/pubmed/24126546

https://www.ncbi.nlm.nih.gov/pmc/PMC4214609/ 
Table 1. Socio-demographic and university training related characteristics of participants

\begin{tabular}{|c|c|c|}
\hline \multirow[t]{2}{*}{ Characteristic } & \multicolumn{2}{|c|}{ Distribution } \\
\hline & $\mathrm{n}$ & $\%$ \\
\hline \multicolumn{3}{|l|}{ Socio-demographic } \\
\hline \multicolumn{3}{|l|}{ Age $($ years) $(n=487)$} \\
\hline $18-24$ & 173 & 36 \\
\hline $25-34$ & 157 & 32 \\
\hline $35+$ & 157 & 32 \\
\hline \multicolumn{3}{|l|}{ Ethnicity $(n=487)$} \\
\hline Caucasian & 408 & 84 \\
\hline Asian & 32 & 6 \\
\hline Aboriginal and Torres Strait Islander & 14 & 3 \\
\hline Others (European, South pacific, Mixed race) & 33 & 7 \\
\hline \multicolumn{3}{|l|}{ Previous education $(n=481)$} \\
\hline High school or STEPS program & 184 & 38 \\
\hline Certificate & 101 & 21 \\
\hline Diploma or bachelor's degree & 196 & 41 \\
\hline \multicolumn{3}{|l|}{ Employment hours per week $(n=487)$} \\
\hline Nil & 112 & 23 \\
\hline $1-10$ & 54 & 11 \\
\hline $11-20$ & 111 & 23 \\
\hline $21-40$ & 182 & 37 \\
\hline $41-60$ & 28 & 6 \\
\hline \multicolumn{3}{|l|}{ Annual personal income (\$AUD) $(n=459)$} \\
\hline$<\$ 20,000$ & 190 & 41 \\
\hline$\$ 20,000-\$ 59,999$ & 200 & 44 \\
\hline$\$ 60,000$ - \$99,999 & 53 & 11 \\
\hline$\geq \$ 100,000$ & 16 & 4 \\
\hline \multicolumn{3}{|l|}{ Living arrangements $(n=487)$} \\
\hline With a partner & 248 & 51 \\
\hline With parents & 95 & 20 \\
\hline With other family members & 61 & 11 \\
\hline With friends/roommate & 49 & 10 \\
\hline Alone & 34 & 7 \\
\hline \multicolumn{3}{|l|}{ Number of children $(n=487)$} \\
\hline None & 271 & 56 \\
\hline $1-2$ & 138 & 28 \\
\hline 3 or more & 78 & 16 \\
\hline \multicolumn{3}{|l|}{ University training related } \\
\hline \multicolumn{3}{|l|}{ Previous nursing experience $(n=470)$} \\
\hline Assistant in Nursing (AIN) & 81 & 17 \\
\hline Enrolled Nurse (EN) & 71 & 15 \\
\hline None & 318 & 68 \\
\hline \multicolumn{3}{|l|}{ Enrolment in $B N(n=487)$} \\
\hline Part-time & 146 & 30 \\
\hline Full-time & 341 & 70 \\
\hline \multicolumn{3}{|l|}{ Clinical placement status* $(n=487)$} \\
\hline Currently involved & 201 & 41 \\
\hline Not currently involved & 286 & 59 \\
\hline
\end{tabular}

*involvement in clinical placement related to $\mathrm{BN}$ at time of completing survey 
Table 2 Factor analysis to group food items based on their factor loading

\begin{tabular}{|c|c|c|c|c|c|c|c|c|}
\hline Food groups & Food items & $\begin{array}{l}\text { Factor } \\
\text { loading }\end{array}$ & Food groups & Food items & $\begin{array}{l}\text { Factor } \\
\text { loading }\end{array}$ & Food groups & Food items & $\begin{array}{l}\text { Factor } \\
\text { loading }\end{array}$ \\
\hline \multirow{9}{*}{$\begin{array}{l}\text { Group 1 } \\
\text { (Snack \& } \\
\text { Fast food) } \\
8.4 \%\end{array}$} & Pizza & .865 & \multirow{5}{*}{$\begin{array}{l}\text { Group 4 } \\
\text { (Salt, Oil \& } \\
\text { Sugar) } \\
22.3 \%\end{array}$} & Salt & .780 & Group 9 & Wine & .769 \\
\hline & Sausages & .795 & & Oil & .730 & $\begin{array}{l}\text { (Alcohol) } \\
38.0 \%\end{array}$ & Sprits & .649 \\
\hline & & & & & & & & \\
\hline & $\begin{array}{l}\text { Prawn/crab } \\
\text { poached with } \\
\text { dressing }\end{array}$ & .783 & & Sugar & .627 & $\begin{array}{l}\text { Group 10 } \\
\text { (Full-fat } \\
\text { dairy) }\end{array}$ & Cheese & .711 \\
\hline & $\begin{array}{l}\text { Potato chips \& } \\
\text { Crisps }\end{array}$ & .737 & & Butter/Margarine & .544 & $40.8 \%$ & Milk: full fat & .517 \\
\hline & $\begin{array}{l}\text { Jam, marmalade } \\
\text { etc. }\end{array}$ & .610 & \multirow{4}{*}{$\begin{array}{l}\text { Group 5 } \\
\text { (Single } \\
\text { Nutrients \& } \\
\text { Probiotics) } \\
25.8 \%\end{array}$} & Folic acid & .791 & & Coffee & .508 \\
\hline & $\begin{array}{l}\text { Vegemite or } \\
\text { marmite }\end{array}$ & .592 & & Calcium & .663 & $\begin{array}{l}\text { Group } 11 \\
\text { (Bacon \& } \\
\text { Eog) }\end{array}$ & Bacon & .783 \\
\hline & $\begin{array}{l}\text { Rice, pasta, } \\
\text { spaghetti, } \\
\text { noodle }\end{array}$ & .472 & & Iron & .618 & $\begin{array}{l}\text { Lgg) } \\
43.6 \%\end{array}$ & Eggs & .542 \\
\hline & $\begin{array}{l}\text { Breakfast cereal, } \\
\text { Muesli }\end{array}$ & .447 & & Probiotics & .455 & $\begin{array}{l}\text { Group } 12 \\
\text { (Protein) }\end{array}$ & Tuna & .773 \\
\hline \multirow{4}{*}{$\begin{array}{l}\text { Group } 2 \\
\text { (Vegetables } \\
\text { \& Legumes) } \\
13.3 \%\end{array}$} & $\begin{array}{l}\text { Cooked, canned } \\
\text { legumes or beans }\end{array}$ & .726 & \multirow{3}{*}{$\begin{array}{l}\text { Group } 6 \\
\text { (Vitamin, } \\
\text { Fish oil \& } \\
\text { Green tea) } \\
28.9 \%\end{array}$} & Fish oil & .723 & $46.2 \%$ & $\begin{array}{l}\text { Protein } \\
\text { supplement }\end{array}$ & .595 \\
\hline & Mushrooms & .705 & & $\begin{array}{l}\text { Multivitamin and } \\
\text { Mineral }\end{array}$ & .590 & $\begin{array}{l}\text { Group } 13 \\
\text { (Fish) } \\
48.7 \%\end{array}$ & Fish & .684 \\
\hline & $\begin{array}{l}\text { Cooked } \\
\text { green/orange } \\
\text { vegetables }\end{array}$ & .657 & & Green Tea & .531 & $\begin{array}{l}\text { Group 14 } \\
\text { (Beer \& Diet } \\
\text { drink) }\end{array}$ & Beer & .778 \\
\hline & $\begin{array}{l}\text { Raw green leafy } \\
\text { or salad } \\
\text { vegetables }\end{array}$ & .654 & $\begin{array}{l}\text { Group } 7 \\
\text { (Meat) } \\
32.1 \%\end{array}$ & $\begin{array}{l}\text { Chicken, or other } \\
\text { poultry }\end{array}$ & .833 & $51.3 \%$ & Diet drinks & .588 \\
\hline
\end{tabular}




\begin{tabular}{|c|c|c|c|c|c|c|c|c|}
\hline & $\begin{array}{l}\text { Potato, sweet } \\
\text { corn }\end{array}$ & .623 & & $\begin{array}{l}\text { Beef, pork or } \\
\text { lamb or other }\end{array}$ & .749 & $\begin{array}{l}\text { Group 15 } \\
\text { (Low-fat } \\
\text { dairy) }\end{array}$ & Milk low fat & .765 \\
\hline & $\begin{array}{l}\text { Dried, frozen or } \\
\text { canned } \\
\text { vegetables }\end{array}$ & .593 & $\begin{array}{l}\text { Group } 8 \\
\text { (Sugary } \\
\text { foods) }\end{array}$ & $\begin{array}{l}\text { red meats } \\
\text { Cake, tart or pie, } \\
\text { pastry. etc. }\end{array}$ & .633 & $53.8 \%$ & $\begin{array}{l}\text { Yoghurt low } \\
\text { fat }\end{array}$ & .537 \\
\hline \multirow{5}{*}{$\begin{array}{l}\text { Group } 3 \\
\text { (Fruit) } \\
18.2 \%\end{array}$} & Dried fruit & .757 & $35.2 \%$ & Chocolate & .506 & \multirow{2}{*}{$\begin{array}{l}\text { Group 16 } \\
\text { (Cereal } \\
\text { based milk } \\
\text { \&yoghurt) } \\
56.2 \%\end{array}$} & $\begin{array}{l}\text { Cereal based } \\
\text { milk }\end{array}$ & .677 \\
\hline & Canned fruit & .724 & & Sugary drinks & .494 & & $\begin{array}{l}\text { Yoghurt full } \\
\text { fat }\end{array}$ & .465 \\
\hline & $\begin{array}{l}\text { Apricots, kiwi, } \\
\text { or plums }\end{array}$ & .719 & & $\begin{array}{l}\text { Hamburger patty } \\
\text { or rissole or } \\
\text { processed meat }\end{array}$ & .451 & $\begin{array}{l}\text { Group } 17 \\
\text { (Water) } \\
58.6 \%\end{array}$ & Water & .705 \\
\hline & Fruit juice & .627 & & $\begin{array}{l}\text { Biscuits, cracker, } \\
\text { etc. }\end{array}$ & .437 & $\begin{array}{l}\text { Group } 18 \\
\text { (Tea) } \\
60.7 \%\end{array}$ & Black tea & .790 \\
\hline & Avocado & .519 & & & & $\begin{array}{l}\text { Group } 19 \\
\text { (Bread } \\
\text { Wholegrain) } \\
62.7 \%\end{array}$ & $\begin{array}{l}\text { Bread } \\
\text { wholegrain/ } \\
\text { multigrain }\end{array}$ & .700 \\
\hline
\end{tabular}


Table 3 Classification of subjects by cluster analysis and distribution of food factors between clusters

\begin{tabular}{|c|c|c|c|c|c|c|}
\hline Food factors & Cluster A $(n=104)$ & Cluster B $(n=150)$ & Cluster C $(n=233)$ & $\mathrm{F}$ & $\mathrm{p}$ & Post hoc \\
\hline Factor 1 (Snack \& Fast food) & $1.48(1.26-1.71)$ & $1.83(1.42-2.24)$ & $1.21(1.11-1.31)$ & 6.7 & 0.001 & $\mathrm{~B}>\mathrm{C}^{* *}$ \\
\hline Factor 2 (Vegetables \& Legumes) & $4.30(3.61-4.99)$ & $3.68(3.25-4.11)$ & $2.43(2.15-2.70)$ & 21.4 & $<0.001$ & $\mathrm{~A}>\mathrm{C}^{* *} ; \mathrm{B}>\mathrm{C}^{* *}$ \\
\hline Factor 3 (Fruit) & $1.04(0.82-1.26)$ & $1.03(0.70-1.35)$ & $0.42(0.34-0.49)$ & 13.5 & $<0.001$ & $\mathrm{~A}>\mathrm{C} * * * ; \mathrm{B}>\mathrm{C} * * *$ \\
\hline Factor 4 (Salt, Oil \& Sugar) & $1.40(1.10-1.71)$ & $3.43(3.03-3.83)$ & $0.75(0.65-0.84)$ & 124.0 & $<0.001$ & $\mathrm{~A}>\mathrm{C}^{* *} ; \mathrm{B}>\mathrm{C} * * * ; \mathrm{A}<\mathrm{B} * * *$ \\
\hline Factor 5 (Single Nutrients \& Probiotics) & $1.49(1.21-1.76)$ & $0.19(0.12-0.27)$ & $0.16(0.11-0.22)$ & 123.4 & $<0.001$ & $\mathrm{~A}>\mathrm{B} * * * ; \mathrm{A}>\mathrm{C} * * *$ \\
\hline Factor 6 (Vitamin, Fish oil \& Green tea) & $2.27(1.90-2.63)$ & $0.42(0.32-0.52)$ & $0.25(0.19-0.31)$ & 160.5 & $<0.001$ & $\mathrm{~A}>\mathrm{B} * * * ; \mathrm{A}>\mathrm{C} * * *$ \\
\hline Factor 7 (Meat) & $0.81(0.65-0.97)$ & $1.05(0.86-1.24)$ & $0.80(0.71-0.89)$ & 3.9 & 0.021 & $\mathrm{~B}>\mathrm{C}^{*}$ \\
\hline Factor 8 (Sugary foods) & $1.01(0.82-1.19)$ & $1.46(0.19-1.72)$ & $1.11(0.95-1.26)$ & 4.6 & 0.010 & $\mathrm{~B}>\mathrm{A}^{*} ; \mathrm{B}>\mathrm{C}^{*}$ \\
\hline Factor 9 (Alcohol) & $0.37(0.20-0.55)$ & $0.25(0.16-0.35)$ & $0.14(0.11-0.20)$ & 6.8 & 0.001 & $\mathrm{~A}>\mathrm{C}^{*}$ \\
\hline Factor 10 (Full fat dairy) & $2.24(1.91-2.56)$ & $3.45(3.07-3.82)$ & $1.51(1.32-1.70)$ & 51.7 & $<0.001$ & $\mathrm{~B}>\mathrm{C}^{* * *} ; \mathrm{B}>\mathrm{A} * * * ; \mathrm{A}>\mathrm{C} * *$ \\
\hline Factor 11 (Bacon \& Egg) & $0.63(0.50-0.76)$ & $0.76(0.63-0.89)$ & $0.35(0.30-0.40)$ & 21.3 & $<0.001$ & $\mathrm{~A}>\mathrm{C} * * ; \mathrm{B}>\mathrm{C}^{* * *}$ \\
\hline Factor 12 (Protein) & $0.71(0.57-0.85)$ & $0.76(0.63-0.88)$ & $0.35(0.30-0.40)$ & 24.3 & $<0.001$ & $\mathrm{~A}>\mathrm{C}^{* *} ; \mathrm{B}>\mathrm{C}^{* * *}$ \\
\hline Factor 13 (Fish) & $0.16(0.11-0.20)$ & $0.11(0.08-0.14)$ & $0.07(0.05-0.08)$ & 11.1 & $<0.001$ & $\mathrm{~A}>\mathrm{C}^{* * *} ; \mathrm{B}>\mathrm{C}^{*}$ \\
\hline Factor 14 (Beer \& Diet drink) & $0.30(0.13-0.47)$ & $0.31(0.20-0.42)$ & $0.34(0.25-0.44)$ & 0.1 & 0.853 & \\
\hline Factor 15 (Low-fat dairy) & $0.46(0.32-0.61)$ & $0.62(0.46-0.78)$ & $0.40(0.31-0.49)$ & 3.5 & 0.031 & $\mathrm{~B}>\mathrm{C}^{*}$ \\
\hline Factor 16 (Cereal based milk \&yoghurt) & $0.57(0.43-0.72)$ & $0.43(0.28-0.57)$ & $0.22(0.16-0.27)$ & 11.7 & $<0.001$ & $\mathrm{~A}>\mathrm{C} * * * ; \mathrm{B}>\mathrm{C} * *$ \\
\hline Factor 17 (Water) & $3.71(3.58-3.83)$ & $3.38(3.22-3.54)$ & $3.28(3.15-3.41)$ & 7.8 & $<0.001$ & $\mathrm{~A}>\mathrm{B}^{*} ; \mathrm{A}>\mathrm{C}^{* * *}$ \\
\hline Factor 18 (Tea) & $0.71(0.55-0.99)$ & $0.37(0.25-0.49)$ & $0.27(0.18-0.35)$ & 14.1 & $<0.001$ & $\mathrm{~A}>\mathrm{B} * * * ; \mathrm{A}>\mathrm{C} * * *$ \\
\hline Factor 19 (Bread Wholegrain) & $0.25(0.16-0.33)$ & $0.46(0.32-0.59)$ & $0.33(0.26-0.40)$ & 3.8 & 0.022 & $\mathrm{~B}>\mathrm{A}^{*}$ \\
\hline
\end{tabular}

Data are presented as mean $\left(95 \%\right.$ confidence interval), ${ }^{*}$ p-value $<0.05 ;{ }^{* *}$-value $<0.01 ; * * *$-value $<0.001$. 
Table 4. Number of serves of ADG-based food groups and their comparison between dietary patterns

\begin{tabular}{|c|c|c|c|c|c|}
\hline & \multirow{2}{*}{$\begin{array}{c}\text { Average } \\
\text { number of } \\
\text { serve intake }\end{array}$} & \multirow{2}{*}{$\begin{array}{c}\text { ADG } \\
\text { serves }^{1}\end{array}$} & \multicolumn{3}{|c|}{ Dietary Patterns } \\
\hline & & & Healthy & Western & Unbalanced \\
\hline Dairy and alternatives & $1.83(1.49)$ & 2.5 & $2.4(1.37)^{\mathrm{a}}$ & $2.5(1.85)^{\mathrm{b}}$ & $1.29(1.02)^{\mathrm{c}}$ \\
\hline Fruit & $1.36(1.62)$ & 2 & $1.89(1.33)^{\mathrm{a}}$ & $1.68(2.27)^{\mathrm{a}}$ & $0.91(1.00)^{\mathrm{b}}$ \\
\hline $\begin{array}{l}\text { Vegetables and } \\
\text { legumes/beans }\end{array}$ & $3.39(2.81)$ & 5 & $4.58(3.61)^{\mathrm{a}}$ & $3.91(2.68)^{\mathrm{a}}$ & $2.52(2.11)^{\mathrm{b}}$ \\
\hline Meat and alternatives & $1.93(1.57)$ & 2.5 & $2.34(1.66)^{\mathrm{a}}$ & $2.37(2.07)^{\mathrm{a}}$ & $1.47(0.88)^{\mathrm{b}}$ \\
\hline Grain (cereal) foods & $1.40(1.31)$ & 6 & $1.35(1.11)^{\mathrm{ab}}$ & $1.71(1.71)^{\mathrm{b}}$ & $1.22(1.03)^{\mathrm{ac}}$ \\
\hline Discretionary foods & $4.96(4.01)$ & $0-2.5$ & $4.52(3.22)^{\mathrm{a}}$ & $7.56(5.32)^{\mathrm{b}}$ & $3.46(2.04)^{\mathrm{c}}$ \\
\hline
\end{tabular}

${ }^{1}$ ADG: Australian Dietary Guidelines - serves based on the recommended average daily number of serves for women aged 19-50 years (National Health and Medical Research Council, 2013). Rows with different letter present a significant difference between dietary patterns $(\mathrm{p}<0.05)$. 
Table 5 Differences in energy, micro- and macronutrients among three dietary patterns

\begin{tabular}{|c|c|c|c|c|c|}
\hline Nutrients & Healthy dietary pattern & Western dietary pattern & Unbalanced dietary pattern & $\mathrm{F}, \chi^{2}$ & p-value \\
\hline Energy $(\mathrm{kJ})$ & $7120.58(2759.32)^{\mathrm{a}}$ & $8002.32(2776.86)^{\mathrm{b}}$ & $5502.9(1987.55)^{\mathrm{c}}$ & 50.1 & $<0.001$ \\
\hline \multicolumn{6}{|l|}{ Macronutrients } \\
\hline Fat $(\mathrm{g})$ & $69.37(29.84)^{\mathrm{a}}$ & $82.03(31.20)^{b}$ & $54.85(22.57)^{\mathrm{c}}$ & 45.7 & $<0.001$ \\
\hline SFA $(g)$ & $25.06(12.38)^{\mathrm{a}}$ & $32.75(15.22)^{b}$ & $21.30(10.41)^{\mathrm{c}}$ & 37.6 & $<0.001$ \\
\hline TFA $(g)$ & $1.03(0.57)^{\mathrm{a}}$ & $1.40(0.65)^{b}$ & $0.90(0.44)^{\mathrm{a}}$ & 38.1 & $<0.001$ \\
\hline Sugar (g) & $74.99(19.42-172.51)^{\mathrm{a}}$ & $83.10(9.59-317.48)^{b}$ & $51.44(13.85-255.66)^{\mathrm{c}}$ & 92.07 & $<0.001$ \\
\hline Fiber $(\mathrm{g})$ & $18.93(4.61-92.06)^{a}$ & $17.47(7.08-68.68)^{a}$ & $11.83(3.22-63.19)^{b}$ & 77.55 & $<0.001$ \\
\hline \multicolumn{6}{|l|}{ Micronutrients } \\
\hline \multicolumn{6}{|l|}{ Vitamins } \\
\hline B6 (mg) & $14.51(0.86-101.13)^{\mathrm{a}}$ & $6.13(0.73-51.72)^{b}$ & $3.37(0.41-27.97)^{\mathrm{c}}$ & 85.65 & $<0.001$ \\
\hline $\mathrm{B} 12(\mu \mathrm{g})$ & $26.29(0.87-107.45)^{\mathrm{a}}$ & $6.24(0.46-56.25)^{b}$ & $3.79(0.28-39.17)^{\mathrm{c}}$ & 84.28 & $<0.001$ \\
\hline Vitamin $\mathrm{C}(\mathrm{mg})^{\ddagger}$ & $147.13(27.54-489.83)^{a}$ & $67.97(12.99-394.68)^{b}$ & $43.39(3.67-353.30)^{\mathrm{c}}$ & 132.02 & $<0.001$ \\
\hline Folate total $(\mu \mathrm{g})$ & $278.50(271.7)^{a}$ & $325.05(288.83)^{a}$ & $195.05(193.68)^{\mathrm{c}}$ & 13.43 & $<0.001$ \\
\hline \multicolumn{6}{|l|}{ Minerals } \\
\hline Sodium $(\mathrm{mg})^{\ddagger}$ & $\begin{array}{l}2742.12(602.67- \\
12720.47)^{\mathrm{a}}\end{array}$ & $2915.93(226.40-12431.68)^{a}$ & $1554.21(91.39-6973.90)^{b}$ & 74.16 & $<0.001$ \\
\hline Potassium (mg) & $\begin{array}{l}2805.12(771.13- \\
11237.28)^{\mathrm{a}}\end{array}$ & $3398.69(1064.12-12031.45)^{a}$ & $1945.50(267.54-5448.83)^{a}$ & 123.66 & $<0.001$ \\
\hline Calcium (mg) & $737.19(490.32)^{a}$ & $786.58(534.73)^{a}$ & $448.59(324.81)^{b}$ & 32.1 & $<0.001$ \\
\hline Iron (mg) & $645.93(783.10)^{a}$ & $556.53(821.16)^{\mathrm{ac}}$ & $442.03(570.19)^{\mathrm{c}}$ & 3.28 & 0.040 \\
\hline Water $(\mathrm{g})$ & $2715.66(752.37)^{a}$ & $2647.62(745.20)^{\mathrm{a}}$ & $1939.03(600.30)^{\mathrm{c}}$ & 69.9 & $<0.001$ \\
\hline Alcohol $(g)^{\ddagger}$ & $2.27(0.00-105.62)^{a}$ & $1.23(0.00-72.60)^{\mathrm{a}}$ & $1.07(0.00-23.57)^{b}$ & 8.74 & 0.013 \\
\hline$\% \mathrm{~kJ}$ from fat & $29.67(8.38)^{\mathrm{ac}}$ & $32.84(9.80)^{b c}$ & $31.55(8.97)^{\mathrm{c}}$ & 3.78 & 0.023 \\
\hline
\end{tabular}

Rows with different letter present significant difference between dietary patterns in each high or normal BP group. Columns with * present a significant difference between normal and high BP group in each dietary pattern. ${ }^{+}$Intakes presented as median $\left(25^{\text {th }}\right.$ percentile $-75^{\text {th }}$ percentile $)$. The remainder intakes are presented as mean $(95 \%$ confidence interval). 
Table 6. The distribution of individual's sociodemographic variables among dietary patterns and their association with Healthy dietary pattern.

\begin{tabular}{|c|c|c|c|c|c|c|c|c|}
\hline $\begin{array}{l}\text { Sociodemograp } \\
\text { hic }\end{array}$ & Healthy & Western & Unbalanced & $\chi^{2}$ & $\begin{array}{c}P \\
\text { value }\end{array}$ & $\begin{array}{l}\text { OR }(95 \% \text { CI, p-value }) \\
\text { for Healthy dietary } \\
\text { pattern vs Others }\end{array}$ & $\begin{array}{l}\text { OR ( } 95 \% \text { CI, p-value) } \\
\text { for Western dietary } \\
\text { pattern vs Others }\end{array}$ & $\begin{array}{l}\text { OR (95\% CI, p-value) } \\
\text { for Unbalanced dietary } \\
\text { pattern vs Others }\end{array}$ \\
\hline Age & & & & 14.3 & 0.006 & & & \\
\hline $18-24$ & $27(15.6)$ & $44(25.4)$ & $102(59.0)$ & & & 1.00 & 1.00 & 1.00 \\
\hline $25-35$ & $38(24.2)$ & $50(31.8)$ & $69(43.9)$ & & & $1.72(0.99-2.99,0.051)$ & $1.37(0.84-2.21,0.198)$ & $0.54(0.35-0.84,0.007)$ \\
\hline$>35$ & $39(24.8)$ & $56(35.7)$ & $62(39.5)$ & & & $1.79(1.03-3.10,0.038)$ & $1.62(1.01-2.61,0.044)$ & $0.45(0.29-0.70,0.000)$ \\
\hline $\begin{array}{l}\text { Living } \\
\text { arrangement }\end{array}$ & & & & 18.33 & 0.019 & & & \\
\hline Alone & $9(26.5)$ & $8(23.5)$ & $17(50.0)$ & & & 1.00 & 1.00 & 1.00 \\
\hline $\begin{array}{l}\text { With friends or } \\
\text { roommate }\end{array}$ & $14(18.6)$ & $6(12.2)$ & $29(59.2)$ & & & $1.11(0.41-2.96,0.833)$ & $0.45(0.14-1.45,0.183)$ & $1.45(0.60-3.50,0.409)$ \\
\hline $\begin{array}{l}\text { With other family } \\
\text { members }\end{array}$ & $14(23.0)$ & $24(39.3)$ & $23(37.7)$ & & & $0.82(0.31-2.17,0.701)$ & $2.10(0.82-5.42,0.122)$ & $0.60(0.259-1.41,0.246)$ \\
\hline With parent(s) & $16(16.8)$ & $24(25.5)$ & $55(57.9)$ & & & $0.56(0.22-1.43,0.221)$ & $1.09(0.43-2.75,0.841)$ & $1.37(0.62-3.02,0.427)$ \\
\hline With a partner & $51(20.6)$ & $88(35.5)$ & $109(44.0)$ & & & $0.72(0.31-1.63,0.432)$ & $1.78(0.77-4.11,0.172)$ & $0.78(0.38-1.61,0.507)$ \\
\hline $\begin{array}{l}\text { Number of } \\
\text { Children }\end{array}$ & & & & 14.78 & 0.005 & & & \\
\hline No children & $55(20.3)$ & $67(24.7)$ & $149(55.0)$ & & & 1.00 & 1.00 & 1.00 \\
\hline $1-2$ & $33(23.9)$ & $54(39.1)$ & $51(37.0)$ & & & $1.23(0.75-2.01,0.400)$ & $1.96(1.26-3.04,0.003)$ & $0.48(0.31-0.73,0.001)$ \\
\hline 3 and more & $16(20.5)$ & $29(37.2)$ & $33(42.3)$ & & & $0.96(0.54-1.89,0.966)$ & $1.80(1.05-3.07,0.031)$ & $0.60(0.36-0.99,0.049)$ \\
\hline Income & & & & 13.91 & 0.031 & & & \\
\hline$<\$ 20,000$ & $27(14.8)$ & $51(28.0)$ & $104(57.1)$ & & & 1.00 & 1.00 & 1.00 \\
\hline$\$ 20,000-\$ 59,999$ & $45(22.7)$ & $72(36.4)$ & $81(40.9)$ & & & $1.68(1.00-2.86,0.050)$ & $1.46(0.95-2.26,0.083)$ & $0.52(0.34-0.78,0.002)$ \\
\hline$\$ 60,000-\$ 99,999$ & $15(28.8)$ & $12(23.1)$ & $25(48.1)$ & & & $2.37(1.12-4.81,0.023)$ & $0.77(0.37-1.58,0.479)$ & $0.69(0.37-1.29,0.248)$ \\
\hline$\geq \$ 100,000$ & $4(25.0)$ & $5(31.3)$ & $7(43.8)$ & & & $1.91(0.57-6.37,0.290)$ & $1.16(0.38-3.52,0.784)$ & $0.58(0.21-1.63,0.305)$ \\
\hline
\end{tabular}

